\title{
418. Kniegelenksoperationen unter arthroskopischer Kontrolle
}

\author{
M. Naber und L. Zwank \\ Kliniken der Stadt Saarbrücken, Winterberg, Akademisches Krankenhaus - Chirurgische Klinik, \\ D-6600 Saarbrücken
}

\section{Knee-Joint Operations Performed with Arthroscopic Visualization}

Summary. Knee-joint operations with arthroscopic visualization require a great deal of experience. Extensive resections take longer than a common arthrotomy, while smaller operations can be completed in a shorter time. In both cases the morbidity is lower than in conventional knee-joint surgery, because the capsule and ligaments of the knee are not opened. We have performed 110 operations with arthroscopic visualization, most of them for partial removal of cartilages. Free mobility was observed after 1 week in $72 \%$ of the patients, and complete recovery of all patients after 4 weeks. No instances of infection were observed in 110 operations and 420 arthroscopies.

Key words: Arthroscopy - Operations of the knee joint - Menisectomy - Operations with the arthroscope.

Zusammenfassung. Operative Eingriffe unter arthroskopischer Sicht setzen ein hohes Maß an diagnostischer Erfahrung voraus. Größere Resektionen dauern länger als eine herkömmliche Arthrotomie, kleinere intraarticuläre Eingriffe sind schneller durchführbar. In beiden Fällen ist die Morbidität geringer, da Kapsel und Bandapparat nicht eröffnet werden. Von uns wurden 110 Eingriffe unter arthroskopischer Kontrolle durchgeführt, wobei die Meniscusteilresektion der am meisten durchgeführte Eingriff war. Wir fanden, daß bei $72 \%$ der Patienten eine freie Beweglichkeit des Kniegelenkes bereits nach einer Woche vorhanden war, bei den übrigen $28 \%$ nach vier Wochen. Infektionen traten sowohl bei 110 Eingriffen als auch bei 420 Arthroskopien nicht auf.

Schliisselwörter: Arthroskopie - Kniegelenksoperationen - Meniscektomie - Arthroskopische Operationen.

\section{Corticalisporose nach Plattenfixation: Streßprotektion oder Zirkulationseffekt?}

\author{
E. Gautier, J. Cordey, U. Lüthi und B. A. Rahn \\ Laboratorium für Experimentelle Chirurgie, Obere Straße 22, CH-7270 Davos-Platz
}

\section{Porosity of Plated Bone After Internal Fixation: Result of Stress Protection or Circulatory Effect?}

Summary. This study was designed to investigate the porosity of plated bone. Plates of different degrees of stiffness were fixed onto in tact ovine tibiae. The disturbance of perfusion (disulphine blue after 4 weeks) and the bone remodelling (fluorescent labelling for 20 weeks) were compared with reference to the plate contact area and the changes in strain pattern of the bone. Blood supply disturbance and bone remodelling area decrease from proximal to distal, and depend on the plate contact area and not on plate stiffness. Early porosis beneath the plate is due to the revitalization of the bone area where perfusion was previously disturbed rather than to stress protection.

Key words: Stress protection - Blood supply - Bone remodelling - Plate contact.

Zusammenfassung. Die Studie untersucht die frühe Corticalisporose nach Verplattung. Unterschiedlich steife Platten wurden auf die intakte Schafstibia montiert. Durchblutungsstörung (Disulfinblau nach 4 Wochen) und Knochenumbau (Fluorescenzmarkierung bis 20 Wochen) wurden mit der Auflagebreite der Platte und der veränderten Knochendehnung verglichen. Durchblutungsstörung und Knochenumbau sind von der Plattenauflagebreite abhängig, haben unter unterschiedlich steifen Platten ein ähnliches Ausmaß und nehmen nach distal ab. Der Knochenumbau ist nicht durch Stressprotektion verursacht, sondern ist Ausdruck der Revitalisierung des durchblutungsgestörten Knochens.

Schlïsselwörter: Streßprotektion - Plattenauflage - Durchblutungsstörung - Knochenumbau. 